\title{
Paclobutrazol and white clover seed production: a non-fulfilled potential
}

\author{
J.G. HAMPTON \\ Seed Technology Centre, Dept of Plant Science, Massey University, Palmerston North
}

\begin{abstract}
Seed yield in white clover depends largely on the number of ripe inflorescences per unit area, and the plant growth regulator paclobutrazol has been used in an attempt to both increase and concentrate inflorescence production, and hence increase seed yield. However results reported from both New Zealand and Europe have been inconsistent, with seed yield responses ranging from highly significant increases to no effects. The current high cost of the chemical ( $\$ 1280 / \mathrm{ha})$ requires a seed increase of over $300 \mathrm{~kg} / \mathrm{ha}$ to ensure an economic return. Similarly no consistent effects of paclobutrazol on white clover vegetative and reproductive growth and development have been established. Possible reasons for this variable response of white clover to paclobutrazol application are presented and discussed.
\end{abstract}

Keywords: inflorescence production, Parlay, reproductive growth, seed yield components, Trifolium repens, vegetative growth

\section{Introduction}

White clover seed yield depends largely on the number of inflorescences produced per unit area (Clifford 1986; 1987). Management practices should therefore be directed at obtaining the high, uniformly distributed stolon tip density needed by the time of closing the crop so that there is a short but prolific flowering span (Clifford 1985; 1987). However achieving the desired stolon tip density is often difficult and efforts to provide the required amounts of mineral nutrients (Clifford \& Rolston 1990) and water (Deschamps \& Wery 1988) can result in excessive vegetative growth. This subsequently reduces inflorescence density and fertility due to the shading effects of competitive leaves (Pasumarty \& Thomas 1990).

A further complication is the intermittent pattern of inflorescence production (Thomas 1987) which dictates that inflorescences appear over a period of time. Seed production in white clover is therefore typical of indeterminate plants (Hollington et al. 1980) in that the extended flowering period and resultant range of inflorescence ripeness categories in the crop makes the determination of optimum harvest time difficult (Budhianto et al. 1995).
The manipulation of white clover to both increase and condense inflorescence production without necessarily producing excessive vegetative growth could be expected to increase seed yield. This hypothesis has been explored using plant growth regulators (e.g. Budhianto et al. 1994a; 1994b). Internationally the most widely trialled plant growth regulator has been paclobutrazol. In this paper, the effects of paclobutrazol on seed production in white clover are reviewed and discussed.

\section{Effects on vegetative growth}

Marshall and Hides (1991a) and Budhianto et al. (1994a) found that paclobutrazol increased nodes per unit area. This response was considered to come from increased stolon production. However, in a study of individual plants in the field, Budhianto (1992) found no increase in main stolon number following paclobutrazol application, but did record a significant increase in the production of fertile secondary and tertiary branches off the main stolons. Whether this occurs in a sward situation is unknown. Both Marshall and Hides (1991a) and Budhianto et al. (1994a) reported an increase in the number of reproductive nodes along main stolons, although Marshall and Hides (1987) and Budhianto (1992) reported that paclobutrazol did not directly induce the initiation of inflorescences.

Paclobutrazol inhibits gibberellin biosynthesis (Hedden 1990) and thus reduces cell elongation. Paclobutrazol reduced white clover petiole length but not peduncle length (Marshall \& Hides 1986; Hampton 1991; Budhianto et al. 1994a), the net effect being to elevate inflorescences above the canopy. While new plant organs which develop following paclobutrazol application are often reduced in size, white clover leaf size and total dry matter at peak flowering were not reduced (Budhianto et al. 1994a).

\section{Effects on reproductive growth and seed yield}

Paclobutrazol application has produced significant white clover seed yield increases in trials reported from Belgium (Rijckaert 1991), Denmark (Boelt \& Nordestgaard 1993), New Zealand (Hampton 1991; Budhianto et al. 1994b) and UK (Marshall \& Hides 1991b). These increases have ranged from $13-350 \%$ 
(Table 1), and in most cases have been explained by an increase in the number of inflorescences at harvest and/ or an increase in the number of seeds per floret or inflorescence (Table 2).

Increased inflorescence production in response to paclobutrazol has generally been a consistent feature (Table 3), but increases in seeds per inflorescence have been more variable (e.g. Hampton 1991; Marshall \& Hides 1991b). This improvement in floret site utilization has been considered to have resulted from a reduction in seed abortion (Hampton 1991), although this is yet to be substantiated. There has generally been no change in the number of florets per inflorescence or in thousand seed weight, but Budhianto et al. (1994b) did report a significant reduction in thousand seed weight in one of two years of trials at the same site.

\section{Variability of results}

While the seed yield responses reported in Table 1 are impressive, nil responses have also been reported. Marshall and Hides (1986) found no increase in cv. Olwen following paclobutrazol application, but also reported (Marshall \& Hides 1991b) that paclobutrazol significantly increased the seed yield of cv. Olwen but not cv. Menna in two consecutive years. Similarly while Hampton (1991) reported a significant increase in the seed yield of cv. G. Pitau, Budhianto et al. (1994b) recorded a non-significant increase in one year and a nil response in the following year for the same cultivar at the same site.

A number of reasons have been suggested for this variability in response to paclobutrazol. They include application rate and time, soil type, cultivar, environmental conditions and time of harvest.

\section{Application rate and time}

Rijckaert (1991) recorded significant seed yield increases at paclobutrazol application rates of $0.25,0.5$ and 1.0 $\mathrm{kg} / \mathrm{ha}$ in two out of three years of trails in Belgium, but Marshall and Hides (1986) found no increase in seed yield at any of these application rates in a trial in UK. Data for paclobutrazol application rate responses are limited, but while most of the significant seed yield responses have come from the $1.0 \mathrm{~kg}$ ai/ha application rate, nil responses at this rate have also been recorded.
Table 2: Major seed yield component increases following paclobutrazol application. ${ }^{1}$

\begin{tabular}{llcc}
\hline $\begin{array}{l}\text { Year of } \\
\text { Harvest }\end{array}$ & Cultivar & $\begin{array}{c}\text { Increase in seeds/ } \\
\text { floret or seeds/ } \\
\text { inflorescence (\%) }\end{array}$ & $\begin{array}{c}\text { Increase in } \\
\text { inflorescences } \\
\text { at harvest (\%) }\end{array}$ \\
\hline 1987 & Milkanova & 19 & -2 \\
1987 & Merwi & 60 & 64 \\
1987 & G. Kopu & 21 & 53 \\
1987 & G. Pitau & 28 & 83 \\
1987 & G. Huia & 54 & 30 \\
1987 & G. Tahora & - & 76 \\
1988 & Olwen & 36 & 61 \\
1989 & Merwi & 38 & 21 \\
1989 & G. Pitau & - & 45 \\
\hline
\end{tabular}

applied at $1 \mathrm{~kg}$ a.i./ha

2 no increase recorded

Table 3: Effect of paclobutrazol on inflorescence number $/ \mathrm{m}^{2}$.

\begin{tabular}{llccc}
\hline Cultivar & Treatment & - & & \\
\hline G. Pitau & & & & \\
& & $1987^{1}$ & $1988^{2}$ & $1989^{2}$ \\
& Nil & 150 & 324 & 588 \\
Olwen $^{6}$ & Paclobutrazol & 210 & 551 & 750 \\
& & $1984^{3}$ & $1987^{4}$ & $1988^{4}$ \\
& Nil & 643 & 562 & 516 \\
& Paclobutrazol & 810 & 703 & 829 \\
\hline
\end{tabular}

${ }^{1}$ Hampton (1991); ${ }^{2}$ Budhianto (1992); ${ }^{3}$ Marshall and Hides (1986); ${ }^{4}$ Marshall and Hides (1991b); ${ }^{5}$ data recorded at peak flowering; 6harvestable inflorescences.

Application has been generally timed for two crop developmental stages - during peak reproductive initiation, or when the reproductive buds/early flowers first become visible (i.e. a time frame of approximately one month between applications). Seed yield responses to application time have varied significantly between seasons at the same site (Marshall \& Hides 1991b), among cultivars in the same seasons at the same site (Hampton 1991), or have produced no significant 
differences between application times in the same cultivar over two seasons at the same site (Budhianto et al. 1994b).

\section{Soil type}

Paclobutrazol is relatively immobile in the soil, being bound mainly by organic matter (Lever 1986). It is possible that soil type may affect the paclobutrazol response, particularly as the chemical is primarily dependant on root uptake (Shearing \& Batch 1982). While soil type may influence the amount of paclobutrazol immediately available for plant uptake, and hence alter the plant response, this does not explain why contrasting results can be obtained at the same site in different seasons (Marshall $\&$ Hides 1991b).

\section{Cultivar}

Marshall and Hides (1991b) considered that cultivars responded similarly to paclobutrazol application, although Hampton (1991) did record differing responses among four New Zealand cultivars (e.g. seeds per inflorescence were significantly increased in three cultivars following paclobutrazol application at the first visible bud stage, but not in a fourth cultivar). The available data suggest greater variability within a cultivar over different seasons than between or among cultivars.

\section{Environment}

The environment always has a significant effect on the success of white clover seed production, but has also been suggested as an explanation for variable paclobutrazol responses, because the chemical requires rainfall during the month after application to enable plant uptake (Hampton \& Hebblethwaite 1984). Marshall and Hides (1991b) related the variability in response to paclobutrazol in two consecutive seasons to the rainfall received in the month after application, but Budhianto et al. (1994b) found different responses in two consecutive seasons when rainfall after application was similar in each season.

\section{Time of harvest}

Wiltshire and Hebblethwaite (1990) reported significant growth regulator $\mathrm{x}$ harvest date interactions for seed yield in Lolium perenne, and Budhianto et al. (1995) explored the hypothesis that paclobutrazol may alter the rate of white clover seed development and therefore the optimum harvest date as compared to the control. However, while paclobutrazol increased inflorescence number at peak flowering, despite large percentage differences, neither ripe inflorescences or seed yield were significantly increased (Table 4). There was also no evidence to suggest that paclobutrazol altered seed development, and paclobutrazol therefore had no effect on optimum harvest time (Budhianto et al. 1995).

Table 4: Effect of paclobutrazol and time of harvest on ripe inflorescence number and seed yield in white clover cv. G. Pitau. ${ }^{1}$

\begin{tabular}{ccccccc}
\hline & \multicolumn{7}{c}{ Harvest time (days after peak flowering) } & Treatment \\
Treatments & 25 & 30 & 35 & 40 & 45 & Means \\
\hline Ripe inflorescences $\left(\mathbf{n o}^{\prime} / \mathbf{m}^{2}\right)$ & & & & & & \\
$\quad$ control & 181 & 153 & 188 & 143 & 71 & 147 \\
$\begin{array}{c}\text { paclobutrazol } \\
\text { Harvest means }\end{array}$ & 317 & 212 & 279 & 167 & 80 & 211 \\
& 249 & 183 & 234 & 155 & 76 &
\end{tabular}

LSD P<0.05: treatment means $=$ NS; harvest means $=63.3$; treatment $x$ harvest $=$ NS C.V. main plots $=24 \%$; subplots $=29 \%$

$\begin{array}{rllllll}\text { Seed yield }\left(\mathbf{g} / \mathbf{m}^{2}\right) & & & & & & \\ \text { control } & 25.5 & 20.8 & 21.1 & 10.0 & 6.2 & 16.7 \\ \text { paclobutrazol } & 37.3 & 28.8 & 36.7 & 17.9 & 9.1 & 26.0 \\ \text { Harvest means } & 31.3 & 24.8 & 28.9 & 14.0 & 7.7 & \end{array}$

LSD $\mathrm{P}<0.05$ : treatment means $=\mathrm{NS} ;$ harvest means $=10.0$; treatment $x$ harvest $=\mathrm{NS}$ C.V. main plots $=44 \%$; subplots $=38 \%$

1 adapted from Budhianto et al. (1995).

\section{Genotypic effects}

As illustrated in Table 4, large percentage differences in seed yield have not always been statistically significant. The high variation recorded (e.g. coefficients of $30 \%$ to $75 \%$, Budhianto 1992; Budhianto et al. 1995) may be attributable to plot size and sample size being too small to allow for the diversity to be found in an outcrossing species such as white clover (although Budhianto (1992) found that increasing plot size, sample size and replicate number did not necessarily reduce the variation recorded). However, it may also be possible that responses to a plant growth regulator may differ with genotype, and that inconsistencies in response to paclobutrazol application may at least in part have been explained by genotypic differences.

Budhianto (1992) examined the effect of paclobutrazol in three genotypes from within cv. G. Pitau. Inflorescence production per plant averaged 320, 400 and 30 for genotypes I, II and III respectively, but paclobutrazol significantly increased inflorescence number $(+32 \%)$ for genotype II only. Total mean seed yield per plant was 74, 57 and $4 \mathrm{~g}$ for genotypes I, II and III respectively, but again, the only significant yield increase following paclobutrazol application was for genotype II $(+25 \%)$. Thus while one genotype responded to paclobutrazol application, two other genotypes did not. However although the seed yield of genotype II 
was increased by paclobutrazol, it was not greater than that produced by the untreated control for genotype I.

These results highlight the importance of genetic factors in determining white clover seed yield. Whether variable responses to paclobutrazol can be explained by differing genotypic responses remains to be determined.

\section{Conclusion}

Although available in New Zealand for horticultural use, paclobutrazol was not released for agriculture, a decision based mostly on concerns about the strong soil residual properties of the chemical and effects on succeeding crops. For white clover this may not be a factor, as Budhianto (1992) reported no effects on vegetative or reproductive growth in plots in year two which had received paclobutrazol at $1.0 \mathrm{~kg}$ ai/ha in year one. While Boelt and Nordestgaard (1993) for example, concluded that plant growth regulators had no place in white clover seed production because of inconsistency of results, the collective evidence suggests otherwise. Certainly an improved understanding of how antigibberellins such as paclobutrazol affect white clover vegetative and reproductive growth is required. However, at the present cost of the chemical $(\$ 1280 /$ ha for a $1 \mathrm{~kg}$ ai/ha application rate), it is not economic. At this price, a grower would need a guaranteed seed yield increase of $320 \mathrm{~kg} / \mathrm{ha}$ (at $\$ 4 / \mathrm{kg}$ seed) and $640 \mathrm{~kg} /$ ha (at $\$ 2 / \mathrm{kg}$ seed) just to recoup the chemical costs. This price is that for the horticultural use of paclobutrazol, and presumably if the chemical was to be released for agricultural use, its cost would decrease commensurately. For the present, paclobutrazol in white clover seed production seems destined to remain a nonfulfilled potential.

\section{Acknowledgement}

I thank Dr B. Budhianto for permission to use unpublished data from his $\mathrm{PhD}$ thesis.

\section{References}

Boelt, B.; Nordestgaard, A. 1993. Growth regulation in white clover (Trifolium repens L.) grown for seed production. Journal of Applied Seed Production 11: 1-5.

Budhianto, B. 1992. Chemical manipulation of white clover (Trifolium repens L.) grown for seed production. PhD thesis, Massey University, Palmerston North, New Zealand.

Budhianto, B.; Hampton, J.G.; Hill, M.J. 1994a. Effect of plant growth regulators on a white clover (Trifolium repens L.) seed crop. I. Plant growth and development. Journal of Applied Seed Production 12: 47-52.

Budhianto, B.; Hampton, J.G.; Hill, M.J. 1994b. Effect of plant growth regulators on a white clover (Trifolium repens L.) seed crop II. Seed yield components and seed yield. Journal of Applied Seed Production 12: 53-58.

Budhianto, B.; Hampton, J.G.; Hill, M.J.; Thomas, R.G. 1995. Effect of time of harvest and paclobutrazol on seed yield in white clover cv. Grasslands Pitau. New Zealand Journal of Agricultural Research 38: $1-6$.

Clifford, P.T.P. 1985. Effect of cultural practice on potential seed yield components of 'Grasslands Huia' and 'Grasslands Pitau' white clover. New Zealand Journal of Experimental Agriculture 13: 301-306.

Clifford, P.T.P. 1986. Interaction between leaf and seed production in white clover (Trifolium repens L.). Journal of Applied Seed Production 4: 37-43.

Clifford, P.T.P. 1987. Producing high seed yields from high forage producing white clover cultivars. Journal of Applied Seed Production 5: 1-9.

Clifford, P.T.P.; Rolston, M.P. 1990. White clover genetic variability and environmental factors affecting seed production. Journal of Applied Seed Production 8: 54-58.

Deschamps, M.D.; Wery, J. 1988. Effect of drought stress and mineral nitrogen supply on growth and seed yield of white clover in Mediterranean conditions. Journal of Applied Seed Production 6: 14-19.

Hampton, J.G. 1991. Effect of paclobutrazol on inflorescence production and seed yield in four white clover (Trifolium repens L.) cultivars. New Zealand Journal of Agricultural Research 34: 367373.

Hampton, J.G.; Hebblethwaite, P.D. 1984. The influence of rainfall on paclobutrazol response in the perennial ryegrass (Lolium perenne L.) seed crop. Journal of Applied Seed Production 2: 8-12.

Hedden, P. 1990. The action of plant growth retardants at the biochemical level. pp. 322-332. In: Pharis R.P.; Rood, S.P. (eds). Plant growth substances 1988. Springer - Verlag, Berlin.

Hollington, P.A.; Marshall, A.H.; Hides, D.H. 1989. Effect of seed crop management on potential seed yield of contrasting white clover varieties. II. Seed yield components and potential seed yield. Grass and Forage Science 44: 189-193.

Lever, B.G. 1986. 'Cultar' - a technical overview. Acta horticulturae 179: 459-466.

Marshall, A.H.; Hides, D.H. 1986. Effect of growth regulators on seed yield components of white clover. Journal of Applied Seed Production 4: 5-7. 
Marshall, A.H.; Hides, D.H. 1987. Modification of stolon growth and development of white clover (Trifolium repens L.) by growth regulators, and its influence on flower production. Journal of Applied Seed Production 5: 18-25.

Marshall, A.H.; Hides, D.H. 1991a. Effect of the plant growth regulator Parlay on the seed production of the white clover cvs. Menna and Olwen. 1. Stolon growth and development. Journal of Applied Seed Production 9: 73-80.

Marshall, A.H.; Hides, D.H. 1991b. Effect of the plant growth regulator Parlay on the seed production of the white clover cvs. Menna and Olwen. II. Yield components and potential seed yield. Journal of Applied Seed Production 9: 81-86.

Pasumarty, S.V.; Thomas, R.G. 1990. The effect of canopy structure and light intensity on seed production in white clover. Proceedings of the New Zealand Grassland Association 52: 107-110.
Rijckaert, G. 1991. Application of growth regulators in seed crops of white clover (Trifolium repens L.) under Belgian climatic conditions. Journal of Applied Seed Production 9: 55-62.

Shearing, S.J.; Batch, J.J. 1982. Amenity grass retardation - some concepts challenged. pp. 467483. In: McLaren, J.S. (ed.). Chemical manipulation of crop growth and development. Butterworths, London.

Thomas, R.G. 1987. Reproductive development. pp. 63-123. In: Baker, M.J.; Williams, W.M. (eds). White clover. Wallingford, CAB International.

Wiltshire, J.J.J.; Hebblethwaite, P.D. 1990. Harvest timing in Lolium perenne L. seed crops treated with the growth regulator triapenthenol. Journal of Applied Seed Production 8: 12-20. 